\title{
Association analysis of genetic polymorphisms and potential interaction of the osteocalcin (BGP) and ER- $\alpha$ genes with body mass index (BMI) in premeno- pausal Chinese women
}

\author{
Hong XU1 ${ }^{1}$, Wen XIAO², Dan LUO ${ }^{1}$, Yong-ming LIU ${ }^{3}$, Lin ZOU ${ }^{4}$, Hai-bin KUANG ${ }^{1, *}$
}

\begin{abstract}
${ }^{1}$ Department of Physiology, School of Medicine, Nanchang University, Nanchang 330006, China; ${ }^{2}$ Department of Pathology, School of Medicine, Nanchang University, Nanchang 330006, China; ${ }^{3}$ Department of Psychology, the Center of Psychological Rehabilitation, Nanchang 330006, China; ${ }^{4}$ Department of Radioimmunology, People's Hospital of Jiangxi Province, Nanchang 330006, China
\end{abstract}

Aim: To investigate whether estrogen receptor $\alpha$ (ER- $\alpha$ ) Pvull and osteocalcin (also known as bone Gla protein, or BGP) Hindlll genetic polymorphisms and their potential interactions are associated with body mass index (BMI) variation.

Methods: Data on BMI and ER- $\alpha$ Pvull and BGP Hindlll genotypes were obtained from 328 healthy premenopausal Chinese women in east China. The study subjects were unrelated, at least 21 years old (mean age of $33.2 \pm 5.9$ years), and had an average BMI of 21.58 \pm 2.59 . All subjects were genotyped at the ER- $\alpha$ Pvull and BGP Hindlll loci using polymerase chain reaction (PCR)-restriction fragment length polymorphism (RFLP).

Results: The BGP Hindlll genotypes were significantly associated with BMI $(P=0.003)$. Carriers of the $\mathrm{HH}$ and Hh genotypes had approximately $2.73 \%$ and $1.27 \%$ higher BMI than those of the hh genotype, respectively. In contrast, the ER- $\alpha$ Pvull polymorphism was not significantly associated with BMI $(P=0.454)$. In addition, there was no evidence of potential interactions between the ER- $\alpha$ and BGP genes in our subjects $(P \geq 0.013)$.

Conclusion: The Hindlll polymorphism of the BGP gene, but not the Pvull polymorphism of the ER- $\alpha$ gene or their potential interaction, was associated with BMI in premenopausal Chinese women.

Keywords: body mass index (BMI); osteocalcin (BGP) gene; estrogen receptor- $\alpha$ (ER- $\alpha$ ) gene; analysis of covariance (ANCOVA)

Acta Pharmacologica Sinica (2010) 31: 455-460; doi: 10.1038/aps.2010.1; published online 22 Mar 2010

\section{Introduction}

Obesity is a serious and complex disease worldwide ${ }^{[1-3]}$. Body mass index (BMI), defined as weight in kilograms divided by the square of height in meters, is a WHO standard index for obesity. BMI is under strong genetic determination with heritability ranging from $20 \%$ to $90 \%^{[4-8]}$. Although genetic factors have a clear role in determining BMI variations, the most substantial genes underlying the variation of BMI are not well identified $^{[9]}$.

The estrogen receptor a (ER-a) gene has been listed as one of 127 possible candidate genes associated with obesity ${ }^{[9]}$. Several lines of recent evidence suggest a potential role for ER-a in the determination of BMI. ER-a may play a critical role in adipose tissue development, metabolism, deposition ${ }^{[10,11]}$ and energy metabolism ${ }^{[12]}$. The estrogen antagonist acting on ER- $\alpha$

\footnotetext{
* To whom correspondence should be addressed.

E-mail kuanghaibin@ncu.edu.cn

Received 2009-07-27 Accepted 2010-01-04
}

can prevent diet- and ovariectomy-induced obesity, mainly by decreasing fat deposition ${ }^{[13]}$. Higher ER-a expression in adipose tissue was observed among obese postmenopausal women ${ }^{[14]}$. The ratio of ER- $\alpha$ to ER- $\beta$ in adipose tissue was associated with obesity in both pre- and postmenopausal women ${ }^{[15]}$. Male ER-a knockout mice have previously been reported to develop obesity after sexual maturity ${ }^{[16,17]}$. Additionally, ER-a levels were associated with BMI in breast cancer patients ${ }^{[18]}$. ER and progesterone receptor status was used to define breast cancer risk factors ${ }^{[19]}$. Polymorphisms in the ER- $\alpha$ gene have been reported to be associated with BMI, though contradictory results were also reported ${ }^{[20-27]}$.

Osteocalcin, also called bone Gla protein (BGP), is an osteoblast-specific protein that is known to play a role in bone growth and has recently been reported to function as a new metabolic hormone regulating the adiposity and glucose homeostasis in experimental animals ${ }^{[28-30]}$. Osteocalcin increases adiponectin and insulin expression in adipocytes and $\beta$-cells, respectively. Osteocalcin-deficient mice also display 
obesity $^{[28]}$. Osteocalcin was suggested to be the only molecule made by osteoblasts that accounts for the osteoblast-mediated regulation of glucose metabolism ${ }^{[31]}$. Serum osteocalcin levels were associated with BMI, glucose metabolism and body fat in several clinical studies ${ }^{[2,32-35]}$.

Due to the importance of ER- $\alpha$ and BGP genes in regulation of adiposity and glucose homeostasis, we hypothesized that genetic polymorphisms and potential interactions of the BGP and ER- $\alpha$ genes were associated with BMI. The polymorphism of the PvuII site in the ER-a gene is the most extensively studied genetic marker in relation to BMI variation. However, the results so far have been largely inconsistent and controversial ${ }^{[20-27]}$. In addition, no data have been provided about the associations between BGP polymorphisms and BMI variation. The most frequently seen polymorphism in the BGP gene is HindIII, which is located in the promoter region. BGP HindIII has been commonly applied in the study of complex traits ${ }^{[36-38]}$. HindIII is, therefore, a possible genetic marker in the search for associations between the BGP gene and BMI variation. Our study was designed to determine whether ER-a PvuII and BGP HindIII polymorphisms were associated with BMI variation and to test whether there was an effect of the interactions between the ER- $a$ and BGP genotypes in determining BMI variation in a population of premenopausal Chinese women.

\section{Materials and methods Subjects}

The study was approved by the Ethical Committee of Nanchang University and People's Hospital of Jiangxi Province. The 328 subjects in this study were recruited from a local population of Nanchang City in east China. They were all of the Han ethnic, comprising greater than $93 \%$ of the total Chinese population. Subjects with diseases, treatments, or conditions that would have an apparent influence on health or contribution to abnormal obesity were excluded. Informed consent was obtained from each subject. For all subjects, a detailed medical history, including menstrual history, was recorded by nurse-administered questionnaires. Information on female history including age at menarche and menopause, years since menopause, and number of births was collected. Physical activity and smoking history were also documented. The subjects were unrelated, healthy, non-smoking and premenopausal women. Body weight was measured to the nearest $0.01 \mathrm{~kg}$ using a digital scale, height was measured to the nearest $0.1 \mathrm{~cm}$ using a wall-mounted stadiometer, and BMI was calculated as weight $(\mathrm{kg})$ divided by height squared $\left(\mathrm{m}^{2}\right)$.

\section{Genotyping}

Genomic DNA was isolated from whole blood using the phenol-chloroform extraction method ${ }^{[39]}$. All subjects were genotyped by polymerase chain reaction followed by restriction fragment length polymorphism analysis (PCR-RFLP). Figure 1 shows the structure of the ER- $\alpha$ and BGP genes and the locations of the studied polymorphisms in the two genes. The ER-a gene is located on chromosome $6 \mathrm{q} 25$ and is composed of 8 exons and 7 introns. The polymorphism of ER-a PvuII is

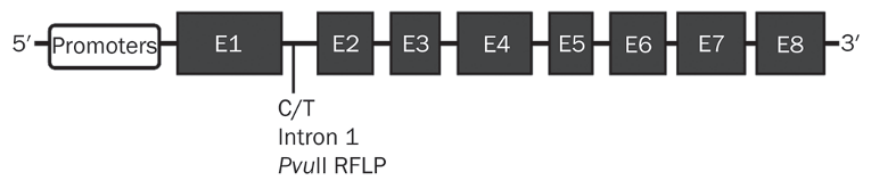

A. The structure of ER- $\alpha$ and the location of the Pvull RFLP marker

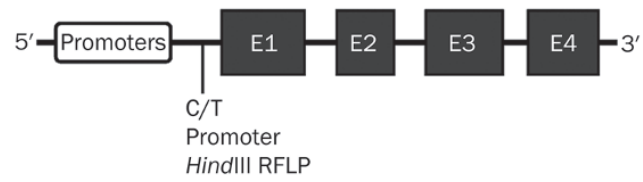

B. The structure of BGP and the location of the HindIII RFLP marker

Figure 1. The structure of the ER- $\alpha$ and BGP genes and the locations of the studied polymorphisms in the two genes. Exons are depicted as filled boxes and introns as single lines between filled boxes.

a C/T single nucleotide polymorphism (SNP) in intron 1 of the ER-a gene. The forward primer (5'-CTG CCA CCC TAT CTG TAT CTT TTC CTA TTC ACC-3') and reverse primer (5'TCT TTC TCT GCC ACC CTG GCG TCG ATT ATC TGA-3') were used to amplify a $1.3 \mathrm{~kb}$ DNA fragment in intron 1 by previously described amplification conditions ${ }^{[40]}$. The BGP gene is located on chromosome 1q25-q31 and is composed of 4 exons and 3 introns. The polymorphism of BGP HindIII is a C/T SNP located in the promoter region of the BGP gene at the 198th nucleotide upstream from exon 1. For the HindIII polymorphism of the BGP gene, a $253 \mathrm{bp}$ DNA fragment was produced using the forward primer (5'-CCG CAG CTC CCA ACC ACA ATA AGC T-3') and the reverse primer (5'-CAA TAG GGC GAG GAG T-3') by previously described amplification conditions ${ }^{[36]}$. After amplification, $8 \mu \mathrm{L}$ of the PCR products was digested with the respective restriction endonucleases, PvuII and HindIII (Promega Corp, Madison, WI, USA), at $65^{\circ} \mathrm{C}$ for $4 \mathrm{~h}$, electrophoresed on a $2 \%$ agarose gel in $1 \times \mathrm{TAE}$ buffer, stained with ethidium bromide, and visualized under UV light. The genotypes were designated as PP, Pp, and pp for PvuII and HH, Hh, and hh for HindIII. Uppercase and lowercase letters represent the absence and presence of the restriction sites, respectively.

\section{Statistical analyses}

All statistical analyses were conducted using SAS version 6.12 (SAS Institute, Cary, NC, USA). The $\chi^{2}$ test was performed to examine Hardy-Weinberg equilibrium (HWE) at the studied marker loci, medical histories, genotype distributions of ER- $\alpha$ PvuII and BGP HindIII polymorphisms, and associations with BMI. The phenotypic values were evaluated for the presence of a normal distribution by the Shapiro-Wilk test. Bartlett's tests were performed to test the homogeneity of variances in BMI between each BGP HindIII and ER-a PvuII genotype. Linear regression analyses were performed to test the impact of medical history on BMI variation. The analysis of covariance (ANCOVA) was used to evaluate the relationship between BMI and each of the ER-a and BGP genetic polymorphisms. The frequency of the HH genotype in the BGP gene was low 
in our subjects $(7.93 \%)$. When the subjects were divided into three groups, $\mathrm{HH}, \mathrm{Hh}$ and $\mathrm{hh}$, the sample sizes were too small to analyze the effect of the polymorphism interaction appropriately. Therefore, the subjects were divided into two groups, those with and without the minor allele, $\mathrm{H}$. To analyze the effect of a special ER-a allele, the subjects with this allele were identified as " 1 " and those without it were identified as " 0 ". ANCOVA was used to test for the effect of a given ER-a gene allele associated with the special BGP genotype. When a significant result was observed, it was interpreted as an interaction between the ER- $\alpha$ and BGP genes. To avoid errors resulting from multiple-testing, Bonferroni corrections were applied to establish an empirical threshold which requires that individual tests have $P$-values $<0.013$ in order to achieve a global significance level of 0.05 for association and interaction analyses in the present study.

\section{Results}

\section{Descriptive characteristics of the study subjects}

The basic characteristics of the 328 unrelated premenopausal women are summarized in Table 1. The ER-a PvuII allele frequencies were $38.6 \%$ for $\mathrm{P}$ and $61.4 \%$ for $\mathrm{p}$ and the BGP HindIII allele frequencies were $28.2 \%$ for $\mathrm{H}$ and $71.8 \%$ for $\mathrm{h}$. The PvuII polymorphism of ER-a and the HindIII polymorphism of BGP were in HWE $(P>0.05)$. Medical histories and genotype distributions of ER-a PvuII and BGP HindIII polymorphisms associated with BMI are listed in Table 2. Linear regression analyses indicated that only age had a significant impact on BMI variation among all the medical history (data not shown) and, thus, age was used to adjust BMI in association and interaction analyses.

Table 1. Basic characteristics of the subjects. $n=328$.

\begin{tabular}{lccrr}
\hline & $\begin{array}{c}\text { Age } \\
\text { (years) }\end{array}$ & $\begin{array}{c}\text { Height } \\
(\mathrm{m})\end{array}$ & $\begin{array}{c}\text { Weight } \\
(\mathrm{kg})\end{array}$ & \multicolumn{1}{c}{$\begin{array}{c}\mathrm{BMI} \\
\left(\mathrm{kg} / \mathrm{m}^{2}\right)\end{array}$} \\
\hline Mean & 33.2 & 1.568 & 55.11 & 21.58 \\
SD & 5.9 & 0.052 & 8.02 & 2.95 \\
Min & 21.3 & 1.450 & 39.00 & 16.24 \\
Max & 38.7 & 1.725 & 87.00 & 30.96 \\
\hline
\end{tabular}

Note: Mean, SD, Min, and Max denote the mean, standard deviation, minimum and maximum values, respectively. BMI values are unadjusted raw data.

\section{Association of the ER- $\alpha$ and BGP genes with BMI}

The analyses did not reveal any significant violations of the assumptions of ANCOVA. For example, the $P$ value was 0.203 for Bartlett's test for homogeneity of variances of BMI among the three BGP HindIII genotypes. The associations between ER- $\alpha$ and BGP with BMI variation are summarized in Table 3. Our analysis revealed a significant association between the BGP HindIII polymorphism and BMI $(P=0.003)$. In our study subjects, individuals with the $\mathrm{HH}$ genotype had the highest BMI $\left(21.81 \pm 0.73 \mathrm{~kg} / \mathrm{m}^{2}\right)$, individuals with the Hh genotype
Table 2. Medical history and genotype distributions of ER- $\alpha$ Pvull and BGP HindIII polymorphisms associated with BMI.

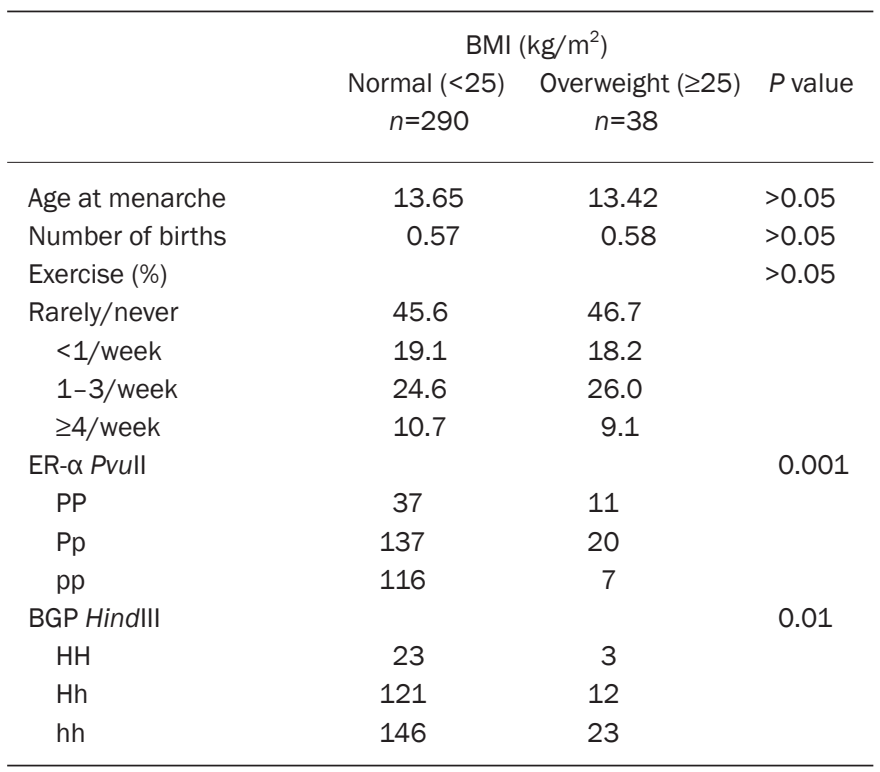

Note:

1. Three subjects $(30<\mathrm{BMI}<31)$ in our population were classified as overweight.

2. The $P$ values were obtained from $t$-tests for continuous variables and $x^{2}$ for categorical variables.

3. ' $n$ ' denotes the sample sizes of the normal and overweight groups.

Table 3. Association analyses for the ER- $\alpha$ Pvull and BGP Hindlll polymorphisms and BMI.

\begin{tabular}{|c|c|c|c|}
\hline Marker & Genotypes & BMI $\left(\mathrm{kg} / \mathrm{m}^{2}\right)$ & $P$ value \\
\hline \multirow[t]{3}{*}{ ER- $\alpha-P v u l l$} & PP (48) & $21.65 \pm 0.58$ & 0.454 \\
\hline & $\mathrm{Pp}(157)$ & $21.63 \pm 0.62$ & \\
\hline & $\mathrm{pp}(123)$ & $21.52 \pm 0.57$ & \\
\hline \multirow[t]{3}{*}{ BGP-HindIII } & $\mathrm{HH}(26)$ & $21.81 \pm 0.73$ & 0.003 \\
\hline & $\mathrm{Hh}(133)$ & $21.50 \pm 0.53$ & \\
\hline & hh (169) & $21.23 \pm 0.63$ & \\
\hline
\end{tabular}

Note:

1. The BMI values are displayed as mean \pm SD of $B M I$ adjusted for age.

2. The values in parentheses are the number of genotypes for each marker.

had intermediate BMI $\left(21.50 \pm 0.53 \mathrm{~kg} / \mathrm{m}^{2}\right)$, and individuals with the hh genotype had the lowest BMI $(21.23 \pm 0.63 \mathrm{~kg} /$ $\mathrm{m}^{2}$ ), on average. Therefore, carriers of $\mathrm{HH}$ and Hh genotypes had approximately $2.73 \%$ and $1.27 \%$ higher BMI, respectively, than those with the hh genotype. We did not observe a significant association between the ER-a PvuII polymorphism and BMI $(P=0.454)$. In addition, the effect of the interactions between the ER-a PvuII and BGP HindIII polymorphisms on BMI is listed in Table 4 . We show that, with the $P$ values of $0.017,0.015,0.020$, and 0.015 , the interactions between a given ER- $\alpha$ gene allele and the special BGP genotype did not have 
significant effects on BMI values (Table 4). Thus, there was no evidence of potential interactions between the ER-a and BGP genes in our subjects $(P \geq 0.013)$.

Table 4. Effects of interaction between the ER- $\alpha$ Pvull and BGP HindIII genes on BMI.

BGP HindIII

A B

\begin{tabular}{llcl}
\hline ER- $\alpha$ Pvull & & & \\
$P$ allele & 1 & $21.74 \pm 0.90(99)$ & $21.30 \pm 0.80(106)$ \\
& 0 & $20.65 \pm 0.88(60)$ & $20.24 \pm 0.85(63)$ \\
& $P$ value & 0.017 & 0.015 \\
p allele & 1 & $21.03 \pm 0.79(130)$ & $20.55 \pm 0.59(150)$ \\
& 0 & $22.36 \pm 0.71(29)$ & $22.07 \pm 0.43(19)$ \\
& $P$ value & 0.020 & 0.015 \\
\hline
\end{tabular}

Note:

1. All data are displayed as mean $\pm S D$ of $B M I$ values adjusted for age.

2. The values in parentheses indicate sample size.

3. " 1 " denotes carriers and " 0 " denotes non-carriers of the corresponding ER- $\alpha$ Pvull allele.

4. "A" denotes the subjects with allele $\mathrm{H}$ (the $\mathrm{HH}$ and $\mathrm{Hh}$ genotypes) at the BGP HindIII locus and "B" denotes the subjects without allele $\mathrm{H}$ (the hh genotype) at the BGP Hindlll locus.

5. $P$ values were calculated by ANCOVA.

\section{Discussion}

In a population of healthy premenopausal Chinese Han women, we showed that the HindIII polymorphism of the BGP gene, but not the PvuII polymorphism of the ER-a gene or their potential interaction, was associated with BMI.

A number of studies have shown that BGP plays an important role in obesity. However, no information regarding the role of BGP polymorphisms in BMI variation is available ${ }^{[28,29,31]}$. With an attempt to disclose the effect of BGP on BMI, we performed an association analysis of the BGP gene and BMI in a cohort of Chinese premenopausal women. The results suggest that the BGP HindIII polymorphism is significantly associated with BMI in our subjects. Considering that the effect of BGP HindIII on BMI may vary between different populations, the effect observed here has yet to be confirmed by separate analyses in different populations or ethnic groups.

Recent studies of the association between the ER-a gene polymorphism and BMI have yielded conflicting results ${ }^{[20-27]}$. Our results are inconsistent with the previous findings in non-Chinese populations, indicating significant associations between the ER- $\alpha$ gene and BMI variation in postmenopausal Caucasian women ${ }^{[20]}$, middle-aged Japanese women ${ }^{[22]}$, postmenopausal white women ${ }^{[21]}$, African-American families ${ }^{[24]}$, Brazilian subjects ${ }^{[25]}$, and men from the Framingham Heart Study ${ }^{[23]}$. However, our findings are consistent with the two previous studies performed on Chinese females ${ }^{[26,27]}$ and a study in women from the Framingham Heart Study showing no effect of the ER-a gene on BMI variation ${ }^{[23]}$. The discrepancies between our study and the other study ${ }^{[23]}$ may be due, partially, to ethnic differences, which may account for the difference in pathogenesis of BMI variation at genetic levels in different ethnic groups. Thus, testing the candidate gene(s) in different populations or ethnic groups is necessary to interpret the peculiar role of the candidate gene(s) in those populations. Additionally, differences in study subjects may partially account for the contradictory results. In the present study, the subjects were all premenopausal women, whereas in the Caucasian study ${ }^{[20,21]}$, subjects were all postmenopausal women. The effect of the ER-a genotype might vary between different periods of a woman's life.

It has been suggested that GXG (gene-by-gene) interactions are a ubiquitous phenomenon in the genetic control of complex traits ${ }^{[41,42]}$. BMI is a complex trait determined by individual genes as well as their potential interactions. Substantial evidence indicates the ER- $a$ and BGP genes may interact with each other to affect the BMI variation from a physiological point of view. Ovariectomy up-regulates and estrogen administration down-regulates the gene expression of osteocalcin in cancellous bone ${ }^{[43]}$, bone marrow mesenchymal stem cells (MSCs) exposed to osteogenic differentiation medium ${ }^{[44]}$, and periosteal cells in the long bones of rats ${ }^{[45]}$. Additionally, serum levels of osteocalcin were significantly elevated in ovariectomized animals compared to intact animals and were reduced by $E_{2}$ and the ER- $a$ agonist ${ }^{[46,47]}$. Intrigued by these findings, we offer insight into the relationship between the ER- $\alpha$ and BGP polymorphism interaction and BMI. Although no evidence of potential interaction between the ER- $\alpha$ and BGP genes in determining BMI was observed in our subjects, the present study represents our efforts to detect and characterize potential GXG effects that determine the genetic contribution to BMI variation that could not be derived from analyzing the individual polymorphisms. Most of the previous genetic studies have focused on the effects of individual genes on $\mathrm{BMI}^{[20-27]}$ irrespective of the effects of interactions among multiple genes. Further studies are required to evaluate and dissect the potential effects of gene interactions on BMI.

It should be noted that the present study has potential limitations. First, we did not completely assess all of the factors related to BMI. Some potential confounding factors such as caloric intake and socioeconomic factors were not included. Second, only one genetic marker was analyzed in each gene in our study due to budget limitations. Further studies examining additional SNP markers that span the entire ER-a and BGP genes are necessary to draw a definitive conclusion on the importance of the ER- $\alpha$ and BGP genes on BMI variation. Next, statistical significance was only observed in a small sample of premenopausal Chinese women. The statistical power decreases considerably with the relatively small sample size. Finally, statistical significance was observed in a regular population association. Further studies employing robust approaches unaffected by population admixture, such as the transmission-disequilibrium test (TDT) ${ }^{[48]}$, are required to confirm our finding. Despite these drawbacks, the current results 
confirm findings of previous studies. Thus, our study is valid in terms of revealing potentially important associations that warrant additional investigation.

In conclusion, we show the HindIII polymorphism of the BGP gene, but not the PvuII polymorphism of the ER-a gene or their potential interaction was associated with BMI in premenopausal Chinese women. The present study represents the first effort to simultaneously investigate the individual effects of the ER- $a$ and BGP genes as well as their potential interactions on BMI variation with an attempt to completely understand the genetic effect underlying BMI. The statistical significance provides confirmation for the need for functional studies on molecular and cellular levels. Further studies in other populations with larger sample sizes and denser markers are required to confirm the findings reported here.

\section{Acknowledgements}

This work was supported by the National Natural Science Foundation of China (No 30760071, 30960118), the Foundation of the Education Department of Jiangxi Province (No GJJ08106), and the Foundation of Nanchang University (№ J06). We thank all the study subjects for their participation in the study.

\section{Author contribution}

Hong XU and Hai-bin KUANG conceived and designed the experiments. Hong XU and Wen XIAO performed the experiments. Hong XU, Wen XIAO, Dan LUO, and Yong-ming LIU analyzed the data. Hong XU wrote the paper. Lin ZOU and Yong-ming LIU helped recruit the study subjects. Hai-bin KUANG revised the paper.

\section{References}

1 Bouchard C. Current understanding of the etiology of obesity: genetic and nongenetic factors. Am J Clin Nutr 1991; 53: 1561S-5S.

2 Brawer R, Brisbon N, Plumb J. Obesity and cancer. Prim Care 2009; 36: 509-31.

3 McMillen IC, Rattanatray L, Duffield JA, Morrison JL, Maclaughlin SM, Gentili S, et al. The early origins of later obesity: pathways and mechanisms. Adv Exp Med Biol 2009; 646: 71-81.

4 Deng HW, Lai DB, Conway T, Li J, Xu FH, Davies KM, et al. Characterization of genetic and lifestyle factors for determining variation in body mass index, fat mass, percentage of fat mass, and lean mass. J Clin Densitom 2001; 4: 353-61.

5 Lajunen HR, Kaprio J, Keski-Rahkonen A, Rose RJ, Pulkkinen L, Rissanen A, et al. Genetic and environmental effects on body mass index during adolescence: a prospective study among Finnish twins. Int J Obes (Lond) 2009; 33: 559-67.

6 Hjelmborg JB, Fagnani C, Silventoinen K, McGue M, Korkeila M, Christensen K, et al. Genetic influences on growth traits of BMI: a longitudinal study of adult twins. Obesity (Silver Spring) 2008; 16: 847-52.

7 Maes HH, Neale MC, Eaves LJ. Genetic and environmental factors in relative body weight and human adiposity. Behav Genet 1997; 27: 325-51.

8 Rice T, Perusse L, Bouchard C, Rao DC. Familial aggregation of body mass index and subcutaneous fat measures in the longitudinal Quebec family study. Genet Epidemiol 1999; 16: 316-34.
9 Rankinen T, Zuberi A, Chagnon YC, Weisnagel SJ, Argyropoulos G, Walts B, et al. The human obesity gene map: the 2005 update. Obesity (Silver Spring) 2006; 14: 529-644.

10 Dieudonne MN, Leneveu MC, Giudicelli Y, Pecquery R. Evidence for functional estrogen receptors alpha and beta in human adipose cells: regional specificities and regulation by estrogens. Am J Physiol Cell Physiol 2004; 286: 655-61.

11 Joyner JM, Hutley LJ, Cameron DP. Estrogen receptors in human preadipocytes. Endocrine 2001; 15: 225-30.

12 Chen JQ, Brown TR, Russo J. Regulation of energy metabolism pathways by estrogens and estrogenic chemicals and potential implications in obesity associated with increased exposure to endocrine disruptors. Biochim Biophys Acta 2009; 1793: 1128-43.

13 Lemieux C, Picard F, Labrie F, Richard D, Deshaies Y. The estrogen antagonist EM-652 and dehydroepiandrosterone prevent diet- and ovariectomy-induced obesity. Obes Res 2003; 11: 477-90.

14 Meza-Munoz DE, Fajardo ME, Perez-Luque EL, Malacara JM. Factors associated with estrogen receptors-alpha (ER-alpha) and -beta (ERbeta) and progesterone receptor abundance in obese and non obese pre- and post-menopausal women. Steroids 2006; 71: 498-503.

15 Shin JH, Hur JY, Seo HS, Jeong YA, Lee JK, Oh MJ, et al. The ratio of estrogen receptor alpha to estrogen receptor beta in adipose tissue is associated with leptin production and obesity. Steroids 2007; 72: 592-9.

16 Geary N, Asarian L, Korach KS, Pfaff DW, Ogawa S. Deficits in E2dependent control of feeding, weight gain, and cholecystokinin satiation in ER-alpha null mice. Endocrinology 2001; 142: 4751-7.

17 Ohlsson C, Hellberg N, Parini P, Vidal O, Bohlooly-Y M, Rudling M, et al. Obesity and disturbed lipoprotein profile in estrogen receptor-alphadeficient male mice. Biochem Biophys Res Commun 2000; 278: 640-5.

18 Giuffrida D, Lupo L, La Porta GA, La Rosa GL, Padova G, Foti E, et al. Relation between steroid receptor status and body weight in breast cancer patients. Eur J Cancer 1992; 28: 112-5.

19 Setiawan VW, Monroe KR, Wilkens LR, Kolonel LN, Pike MC, Henderson $\mathrm{BE}$. Breast cancer risk factors defined by estrogen and progesterone receptor status: the multiethnic cohort study. Am J Epidemiol 2009; 169: 1251-9.

20 Deng HW, Li J, Li JL, Dowd R, Davies KM, Johnson M, et al. Association of estrogen receptor-alpha genotypes with body mass index in normal healthy postmenopausal Caucasian women. J Clin Endocrinol Metab 2000; 85: 2748-51.

21 Goulart AC, Zee RY, Rexrode KM. Estrogen receptor 1 gene polymorphisms and decreased risk of obesity in women. Metabolism 2009; 58: 759-64.

22 Okura T, Koda M, Ando F, Niino N, Ohta S, Shimokata H. Association of polymorphisms in the estrogen receptor alpha gene with body fat distribution. Int J Obes Relat Metab Disord 2003; 27: 1020-7.

23 Fox CS, Yang Q, Cupples LA, Guo CY, Atwood LD, Murabito JM, et al. Sex-specific association between estrogen receptor-alpha gene variation and measures of adiposity: the Framingham Heart Study. J Clin Endocrinol Metab 2005; 90: 6257-62.

24 Gallagher CJ, Langefeld CD, Gordon CJ, Campbell JK, Mychaleckyj JC, Bryer-Ash $\mathrm{M}$, et al. Association of the estrogen receptor-alpha gene with the metabolic syndrome and its component traits in AfricanAmerican families: the Insulin Resistance Atherosclerosis Family Study. Diabetes 2007; 56: 2135-41.

25 Mansur AP, Nogueira CC, Strunz CM, Aldrighi JM, Ramires JA. Genetic polymorphisms of estrogen receptors in patients with premature coronary artery disease. Arch Med Res 2005; 36: 511-7.

26 Jian WX, Yang YJ, Long JR, Li YN, Deng FY, Jiang DK, et al. Estrogen 
receptor alpha gene relationship with peak bone mass and body mass index in Chinese nuclear families. J Hum Genet 2005; 50: 477-82.

27 Chen Y, Jiang XY, Xu L, Li X, Cao FF, Li L, et al. Association of ER-alpha gene polymorphism with metabolic phenotypes in Chinese Hans. Lipids 2009; 44: 719-23.

28 Lee NK, Sowa H, Hinoi E, Ferron M, Ahn JD, Confavreux C, et al. Endocrine regulation of energy metabolism by the skeleton. Cell 2007; 130: 456-69.

29 Pittas AG, Harris SS, Eliades M, Stark P, Dawson-Hughes B. Association between serum osteocalcin and markers of metabolic phenotype. J Clin Endocrinol Metab 2009; 94: 827-32.

30 Ferron M, Hinoi E, Karsenty G, Ducy P. Osteocalcin differentially regulates beta cell and adipocyte gene expression and affects the development of metabolic diseases in wild-type mice. Proc Natl Acad Sci U S A 2008; 105: 5266-70.

31 Lee NK, Karsenty G. Reciprocal regulation of bone and energy metabolism. Trends Endocrinol Metab 2008; 19: 161-6.

32 Kanazawa I, Yamaguchi T, Sugimoto T. Relationships between serum osteocalcin versus serum glucose and lipids levels and atherosclerosis in type 2 diabetes mellitus. J Bone Miner Res 2009; 160: $265-73$.

33 Kanazawa I, Yamaguchi T, Yamamoto M, Yamauchi M, Kurioka S, Yano S, et al. Serum osteocalcin level is associated with glucose metabolism and atherosclerosis parameters in type 2 diabetes mellitus. J Clin Endocrinol Metab 2009; 94: 45-9.

34 Kindblom JM, OhIsson C, Ljunggren O, Karlsson MK, Tivesten A, Smith $U$, et al. Plasma osteocalcin is inversely related to fat mass and plasma glucose in elderly Swedish men. J Bone Miner Res 2009; 24: 785-91.

35 Fernandez-Real JM, Izquierdo M, Ortega F, Gorostiaga E, GomezAmbrosi J, Moreno-Navarrete JM, et al. The relationship of serum osteocalcin concentration to insulin secretion, sensitivity, and disposal with hypocaloric diet and resistance training. J Clin Endocrinol Metab 2009; 94: 237-45.

36 Gustavsson A, Nordstrom P, Lorentzon R, Lerner UH, Lorentzon M. Osteocalcin gene polymorphism is related to bone density in healthy adolescent females. Osteoporos Int 2000; 11: 847-51.

37 Wu HC, Lin CC, Chen WC, Chen HY, Tsai FJ. Osteocalcin gene
HindIII C/T polymorphism is a biomarker for prostate cancer and responsiveness to hormone therapy. Eur Urol 2003; 43: 197-200.

38 Chen WC, Chen HY, Wu JY, Chen YT, Tsai FJ. Osteocalcin gene HindIII polymorphism is not correlated with calcium oxalate stone disease. Urol Res 2001; 29: 98-101.

39 Lu SD. Current Protocols for Molecular Biology, 2nd edn, Peking Union Medical College Press, Beijing; 1999, p 102-108.

40 Kobayashi S, Inoue S, Hosoi T, Ouchi Y, Shiraki M, Orimo H. Association of bone mineral density with polymorphism of the estrogen receptor gene. J Bone Miner Res 1996; 11: 306-11.

41 Zhang YY, Long JR, Liu PY, Liu YJ, Shen H, Zhao L, et al. Estrogen receptor alpha and vitamin $\mathrm{D}$ receptor gene polymorphisms and bone mineral density: association study of healthy pre- and postmenopausal Chinese women. Biochem Biophys Res Commun 2003; 308: 777-83.

$42 \mathrm{Xu} \mathrm{H}$, Long JR, Li MX, Deng HW. Interaction effects between estrogen receptor alpha and vitamin $D$ receptor genes on age at menarche in Chinese women. Acta Pharmacol Sin 2005; 26: 860-4.

43 Salih MA, Liu CC, Arjmandi BH, Kalu DN. Estrogen modulates the mRNA levels for cancellous bone protein of ovariectomized rats. Bone Miner 1993; 23: 285-99.

44 Hong L, Colpan A, Peptan IA. Modulations of 17-beta estradiol on osteogenic and adipogenic differentiations of human mesenchymal stem cells. Tissue Eng 2006; 12: 2747-53.

45 Turner RT, Colvard DS, Spelsberg TC. Estrogen inhibition of periosteal bone formation in rat long bones: down-regulation of gene expression for bone matrix proteins. Endocrinology 1990; 127: 1346-51.

46 Hertrampf T, Schleipen B, Velders M, Laudenbach U, Fritzemeier KH, Diel P. Estrogen receptor subtype-specific effects on markers of bone homeostasis. Mol Cell Endocrinol 2008; 291: 104-8.

47 Seidlova-Wuttke D, Prelle K, Fritzemeier KH, Wuttke W. Effects of estrogen receptor alpha- and beta-selective substances in the metaphysis of the tibia and on serum parameters of bone and fat tissue metabolism of ovariectomized rats. Bone 2008; 43: 849-55.

48 Xu H, Zhao LJ, Lei SF, Li MX, Sun X, Deng FY, et al. The (Ca)n ppolymorphism of the TNFR2 gene is associated with peak bone density in Chinese nuclear families. J Hum Genet 2005; 50: 301-4. 